\title{
NGAHUMA (PLANTING RICE IN THE FIELDS) AND TILLED LAND LIMITATION OF THE BADUY TRIBE IN INDONESIA
}

\author{
Kholil Lur ROCHMAN" \\ Institut Agama Islam Negeri (IAIN) Purwokerto, Faculty of Da'wah, Indonesia, e-mail: cholil@iainpurwokerto.ac.id \\ MISNO \\ Institut Agama Islam Sahid, Departement of Sharia Economics, Indonesia, e-mail: drmisnomei@gmail.com
}

Zahid MUBAROK

Pascasarjana PUI Majalengka, Faculty of Islamic Education, Indonesia, e-mail: mujahidmujahid2016@gmail.com

BUNYAMIN

STAI Syamsul ‘Ulum, Departement of Islamic Family Law, Indonesia, e-mail: bunyamin@ staisyamsululum.ac.id

\section{BAHRUDIN}

STAI Syamsul 'Ulum, Departement of Islamic Family Law, Indonesia, e-mail: bahrudin@ staisyamsululum.ac.id

\author{
Citation: Rochman, K.L., Misno, Mubarok, Z., Bunyamin, \& Bahrudin. (2020). NGAHUMA (PLANTING RICE IN THE FIELDS) AND TILLED \\ LAND LIMITATION OF THE BADUY TRIBE IN INDONESIA. GeoJournal of Tourism and Geosites, 34(1), 63-68. \\ https://doi.org/10.30892/gtg.34109-620
}

\begin{abstract}
Baduy are traditional native Indonesian tribes living in the southeastern part of the province of Banten, and they are considered as a tribe reliable in upholding ancestral traditions. One of their customary laws is the obligation to ngahuma (planting rice in the fields) as a form of worship and harmony. The main purpose of this research is to describe whether the Ngahuma customary law will continue in the dilemma of land limitations. This recent study will propose several solutions related to their customary law sustainability and their economic needs. The descriptive qualitative method was employed as a tool for examining Baduy tribe-related phenomena. Using participatory observation, interviews, and literature study, this exploratory research examines and analyzes traditional activities, obligations, ngahuma in the context of the baduy community. This research study utilized four key informants and three validators to achieve thematic saturation. Based on our findings, we conclude that the Baduy population increases even though the land for ngahuma remains the same. Moreover, ngahuma is a traditional customary obligation that cannot be violated. Some solutions have been found, such as buying or renting land outside customary land, limiting the fallow (do not use the land before replanting), and dividing land to family members. However, several problems remain; for example, unfertile land conditions and lack of rice for the community. Finally, researchers offer solutions and expected the local government of the Lebak Regency to provide new land for the Baduy tribe.
\end{abstract}

Key words: Baduy Tribe, Ngahuma, tilled land, land limitation, Harmony

\section{INTRODUCTION}

Baduy is one of the unique Indonesian tribes living in the province of Banten. As an indigenous Indonesian ethnic group, they have a stronghold belief in the ancestral tradition (Sutisna, 2019). Today, the Baduy people are still consistent with their customary beliefs, rejecting all forms of modernization, refuses to use modern equipment. Their community is also refusing all forms of transportation and all media communications and its taboos to study in the formal educational institutions (Bukhori-Muslim, 2015). Obedience to a mirrored custom is the beginning of the beliefs with the philosophy "Long must not be cut, Short must not be joined, mountains cannot be destroyed, valleys must not be destroyed. Great-grandmother must not be changed, if you slash/cut, if you cut it, it must match the size, if you slough off, then it must be appropriate as it is, if you speak you must be right, wrong is wrong, right is right, you cannot lie, you cannot take sides" (Mohammad, 2017, p.21) Furthermore, it was emphasized by their primary tasks for nurturing and guiding the queen/king and leader, cleaning and praying and maintaining the balance of nature, affirming and confirming wiwitan (religious belief system of Baduy people), it is not being given the task to enliven the State. One of the customary laws that become the obligation of worship is ngahuma, which is planting rice in the fields (Iskandar and Iskandar, 2017b). As a traditional leader from the village of Cibeo Baduy Dalam, Jaro Sami states that Ngahuma is one of the traditional obligations that must be carried out until doomsday (Khomsan and Wigna, 2009). Therefore, they have their terms "Even though there is only one coconut shell seed, ngahuma still must be done." This local wisdom is undoubtedly a form of Baduy cultural wisdom because it is analyzed more deeply that ngahuma is very closely related to the fulfillment of their daily needs, especially rice. Even if their crop yields are small, of course, it will not be able to meet their needs (Iskandar et al., 2018c). However, this is still maintained by the Baduy people. The preservation of culture or custom (ngahuma) is impressive (Putri et al., 2019) as a form of local cultural wisdom of the Baduy people (Hidayati et al., 2020).

Whereas other customary legal systems, especially for Baduy Dalam, they are not allowed to trade, because according to them, trading activities lead to lies and deception (Solikhah, 2020). So far, in the three Baduy Dalam villages, no one has opened a shop to trade; even if some sell, they are people from outside the Baduy village (Tou et al., 2010). This culture is maintained as a form of Baduy leadership that has charismatic and obeyed by the community. Obedience is from the impact of a representative and recognized leadership (Hakiki, 2015).

The problem is that their numbers are increasing while the land area remains the same (Taryana, 2020). Land management pattern using fallow systems (do not use the land before replanting) for one year, resulting in reduced soil fertility. This practice has an impact on their diminishing income. Will their customary law continue to deal with this dilemma? What solutions can be made to keep their customary law sustainable and their economic needs also met? 


\section{MATERIALS AND METHODS}

\section{Method}

A qualitative descriptive approach was used in this study as the research methodology. Descriptive qualitative research produces descriptive data in the form of written or oral words from people and observable behavior (Huberman and Miles, 2002). This research's object was the Baduy people and their ngahuma customary obligation (planting rice in the fields). Data collection techniques used in this study were observations of participation, interviews, and literature study. An observation approach for social and behavioral activities, social status, the tradition of ngahuma obligations (planting rice in the fields), and their culture also employed to collect the data (Becker et al., 2002). This study explores the most common data collection methods, with interviews between informants and interviewers consisting of seven people interviewed representing each group and primary source. The secondary data was reserved from literature study in the form of books, scientific works, or writing-related to texts relevant to the theme studied, visual documents relating to photographs of the Baduy community's cultural activities, especially the obligation to ngahuma (planting rice in the fields).

An inductive approach was utilized to generate meanings from the data set collected to categorize patterns and relationships (Thomas, 2006). Additionally, to develop a comprehensive understanding of phenomena, we used the triangulation method, which consisted of grouping data, analyzing data, and conclusions (Jonsen and Jehn, 2009).

\section{RESULTS DISCUSSIONS}

\section{Ngahuma as a Customary Legal System of Baduy People}

Baduy Dalam is the past Baduy people's living culture who approaches the original heir of the culture and their tribal ancestors' mandate. The term original heir only refers to the level of obedience and awareness of their community in maintaining their customs and consistency to shut themselves away from negative foreign cultural influences (Utomo et al., 2020). The argument that reinforces this assumption is that there is a specific stipulation of the Baduy Dalam village area, which is only located in 3 villages, namely Cibeo, Cikartawana, and Cikeusik fixed, strict legal boundaries and is binding on all parties and all aspects of their lives. Including the boundaries and cubication of the area, which became the authority between the three villages (Ardan, 2008). Baduy Luar is a Baduy community prepared as a guard, cantilever, filter, protector, and at the same time as an intensive friendship connector with outside Baduy as a form of appreciation, cooperation, and active participation in state activities to show that they are one of the same ethnic groups. They have equal rights and obligations with other Indonesian citizens (Ichwandi and Shinohara, 2007). The Baduy tribe firmly holds Pikukuh Karuhun, a doctrine that requires them to do various things as their ancestors (Nadroh, 2018). Pikukuh Karuhun requires them to (1) Pray for the Wellbeing and Safety of the World Center and the Universe (Ngabaratapakeun - ngabaratanghikeun); (2) Preserve the Continental Heritage Site (Sasaka Domas); (3)Take care of the Queen guides the noblemen (Ngasuh Ratu Nyayak Menak); (4) Respect the Guriang (ancestral spirits) and perform the Muja; (5) Preserve and maintain the Custom of the Bulan Kawalu (Eight-Month); (6) Organize and respect the Ngalaksa customary ceremony; (7) Perform the Seba Ritual once a year, at the beginning of the Custom Calendar year; (8) Farm (Ngahuma).

Ngahuma or cultivating rice is one of the pillars of the Wiwitan (religious belief system of Baduy people), so under any circumstances, they must perform ngahuma (Sodikin, 2017). According to an interview with Jaro Sami, one of the Baduy Dalam community leaders stated that "ngahuma is a traditional obligation that must be carried out until the end of the world. It is true that if more people increase, the land will decrease because even though the land decrease, ngahuma must be carried out, this should not be abandoned even until doomsday".

This opinion is supported by other Baduy community leaders, who stated, "according to our customary law, even though there is only ONE SEED, ngahuma is mandatory, and it cannot be abandoned even until the world is doomed, because of the necessity of these rules for residents. Moreover, it is included in the wiwitan traditional harmony (Interview on Friday, April 19, 2019).

Referring to the customary law, it is compulsory for all members of the Baduy tribe to ngahuma, planting rice in the fields. As a worship ritual, ngahuma is a manifestation of worship to Nyi Pohaci as the guardian goddess of rice (Holil, 2020). As a tribe, Baduy respects rice because rice is always utilized in almost all of their rituals. Rice is so sacred to their community; hence, in every process of planting, maintaining, harvesting, and storing up to consuming, it must be following the rituals tradition of worshiping the goddess of rice and fertility. So, it is not surprising if ngahuma is part of the wiwitan pillars because if there is no more rice planting, there will be no more worship to Dewi Sri (Barendregt and Wessing, 2008). This reason also makes the prohibition, especially for Baduy Dalam, to trade. The logical reason is that trading activities contain many lying elements, so they are prohibited from selling or trading. This prohibition is somewhat more lenient for Baduy Luar; now, almost every Baduy Luar villager opens a stall in their house. This habit is following what has been stated by Hakiki (2015) that there are no trades of Baduy; they mostly grow rice in the fields or farms (Figure 1).

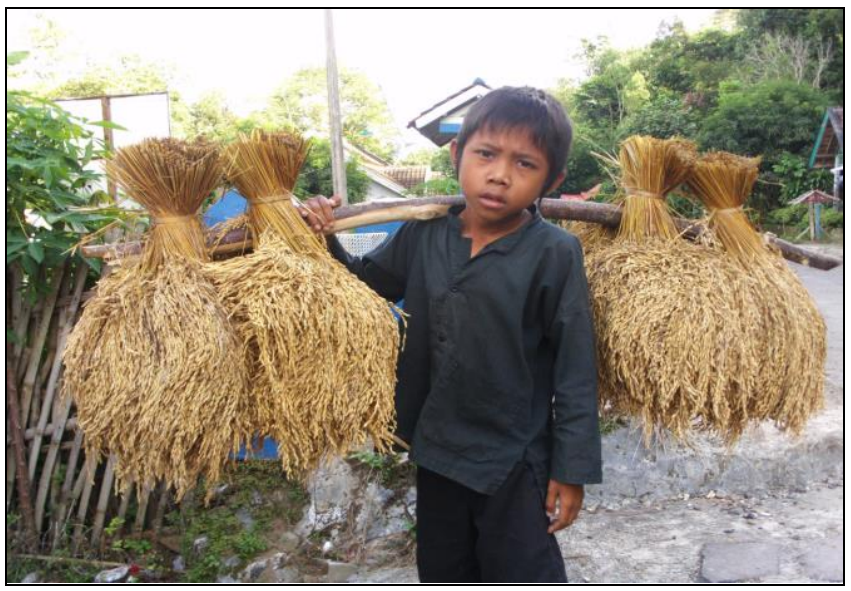

Figure 1. The Baduy Ngahuma Tradition (Source: research documentation by the author, 2019)

The problem that arises is that their land never increases while the population continues to grow. Thus it forces them to change their farming systems. If they had shifted cultivation in the past, and the time lag for returning to work on the land was five years now, their land is getting narrower. The time lag is only one year, even in some locations of huma planted continuously. The impact is low rice fertility, so 
that the crops are also low. Even in recent years, there have been crop failures. This condition will make their rice needs nutrition fulfilled so that in the last few years, they have bought rice from outside or government assistance; it is called Raskin (rice for the poor). Consistent with the opinion of Permana et al., (2017), which stated that space for the Baduy tribe in the future would be limited. Further, the increasing population of the tribe will be a problem in the future.

\section{Baduy Dilemma: Between the Obligations of Ngahuma and the Limitations of Huma Land}

The Baduy dilemma faced today is the increase in their population, but the land remains the same. Even though they should do ngahuma, will this customary law continue to survive or slowly be modified or violated? According to the expert, when a law cannot adopt the community's needs, the law will be abandoned or modified. This circumstance is what happened to the Baduy. The obligation to make the Baduy luar flock to buy land outside of customary land cumulatively reached almost 1,200 hectares in 2019 (Mulyadi et al., 2019).

More than half of Baduy-Luar residents work outside the customary land in 10 subdistricts; they are Leuwidamar, Muncang, Subang. Bojongmanik, Cirinten, Gunungkencana, Cimarga have even reached Sajira, Cijaku, and Malingping (Kismartini and Pujiyono, 2020). Mostly, they rent land or join for profit sharing, while the Baduy-Dalam people are forced to start shortening the rest period (fallow) of their land. Simultaneously, they were minimizing the area of their cultivation because it is shared relatively due to the increasing number of families required to work in the fields. While other livelihoods as an alternative income are also restricted, including openly trading in residential areas, this polemic and dilemma are quite frightening to their future survival if there is no solution from the government and different point of view from them. The term Baduy Dalam food self-sufficiency and Baduy prosperous with their customary choices are no longer relevant (Chalil et al., 2018). This problem has arisen since 2015; traditional leaders began actively discussing the need for additional land for their needs, which were conveyed at certain events. both on peduliawan Baduy or Negara, and at the Seba Gede May 28, 2017, at the Multatuli pavilion in Lebak Regency, "Jaro Saija and Tanggungan 12 represent the Baduy party openly propose a formal return to the local and central government regarding the addition of 1000 hectares to their customary land area".

The root of the problem is that every family in the Baduy tribe is required without exception for farming (ngahuma) (Iskandar, 2007a). In April 2018, the number of patriarchs had reached 3,395; in Baduy Dalam, there are $308 \mathrm{HHs}$. If at least each $\mathrm{HH}$ needed half a hectare to farm, in 2018, it would require 1,697.5 Hectares of vacant land, while Baduy Dalam would require 154 Hectares. Currently, in 2019, there are more than 3,500 households, meaning that this year requires vacant land to be cultivated into a HUMA is 1,750 hectares. The difference in the need for one year's vacant land is 53 hectares (Iskandar and Iskandar, 2017b). Simultaneously, the 2,136.58 hectares of cultivated land in the Customary Land area continues to be used as new settlements. Currently, in 2019, they have reached 67 villages. The Baduy Dalam residents are prohibited from farming outside the Baduy Dalam Customary land. According to their claim, the area of arable land and for Baduy residents is not more than 700 hectares for three villages because the 3000-hectare land has been designated as "Leuweung Kolot," which should not be used for farming. Referring to this fact, there are several aspects of the study of the main problems in the Baduy tribal dilemma, especially the legal aspects of the obligation of ngahuma in the Baduy tribe (Field note, 2019):

1. The need for fertile vacant land is increasing in line with population growth and the household head.

2. The availability of vacant land outside customary land is increasingly difficult, especially in customary land, which is impossible to increase.

3. The narrower the land used for farming, the less certain crops will be.

4. The shorter the rest period (fallow) of the land, the less the level of fertility.

5. The cost to work on Huma is considerable, but income is decreasing because soil fertility is increasingly lost, and the land is increasingly narrow, and seasons are uncertain.

6. The need to eat increases and income decreases because of the population growth, and another prohibition of the Baduy people from trading.

Concerns about nature and the changing times according to Ayah Karmain s, one of the Baduy Dalam community leader, he stated that what influenced their ethnicity was so powerful that they were forced to face problems and dilemmas; crushed if one does, destroyed if one does not (maju asup jurang mundur asup jungkrang) (Field note, 2019). The fulfillment of necessities of life, especially food, is increasing. However, at the same time, it is increasingly difficult to obtain because of the harsh competition. While the lan d that provides the crops in the customary land area is getting narrower and decreases its' fertility, on the other hand, the tightness, rigidity of customary law also leads to dilemmas and problems for them. This condition is worsened by the modernization \& globalization through advances in communication technology internalization) which increasingly penetrate their territory. The multicomplex of life problems they face has led to difficult decision-making. It is eventually forcing them to adapt themselves ion $\mathrm{n}$ the process of dynamism, cultural hybridization, and adoption of modern lifestyles. However, they are aware that slowly but surely, it will undermine their social and cultural order without even noticeably shifting step by step. The customary law's legality follows the positive law \& modern lifestyle.

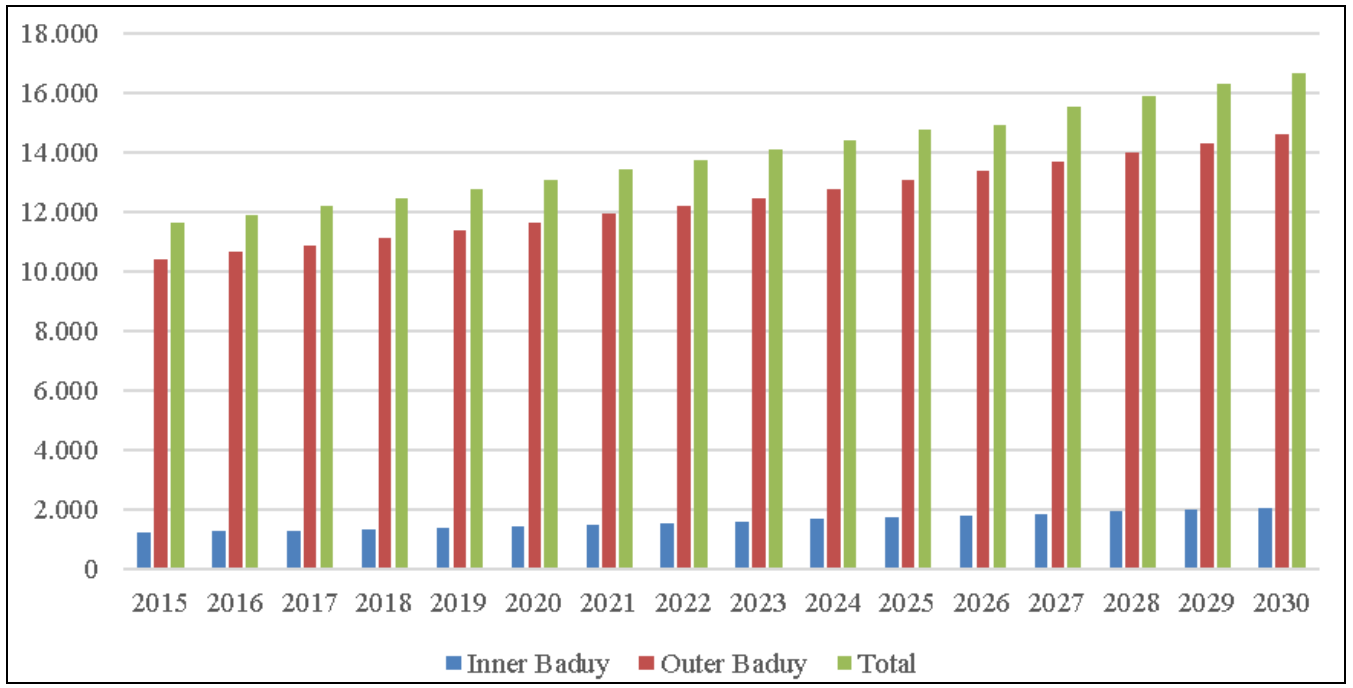

Figure 2. Estimated Growth of Baduy population 2015-2030 ( BPS, 2019) 
There have been many customary prohibitions and taboo, which they change by breaking the rules. They have now become habits that are applied in their daily lives. The resistance between meeting the needs of a comfortable life with the standardization of customary rules becomes a unique story that is prolonged and hereditary, especially in the Baduy Dalam traditional community. Suppose the stagnation and rigidity of customary law do not allow for social engineering. In that case, predictions and forecasts of food shortages will hit their tribes; they are just waiting even the authors dare to speculate \& predict the extinction of Baduy culture and cust omary law can occur more quickly and horrifically. According to fears, Mr. Jaro Tangtu Sami stated that it would be found in the years to come: "Baduy but different Baduy"(Field note, 2019). Prediction of population growth based on average population growth in the next 15 years is as follows:

Referring to this estimation graphic (Figure 2), then, in Baduy Dalam: $308-152=166$, the percentage increase in 15 years is $166 / 308 \mathrm{x}$ $100 \%=53.9 \%$. means per year, $53.9 \%$ divided by $15=3.6 \%$ / year. While Baduy luar: $3,087-1,535=1,552$, then the percentage increase in 15 years is $1,552 / 3,087 \times 100 \%=50.3 \%$, meaning per year, $50.3 \%: 15=3.4 \%$ per year

Based on Figure 3, In April 2015, the number of heads of households had reached 3,395; in Baduy Dalam, there are 308 heads of households. If at least each household head needs half a hectare to farm, this year will need 1,697.5 Hectares of wasteland, in Baduy Dalam needs 154 Hectares. Currently, in 2019 the number of heads of households has more than 3,500. It means that this year needs wasteland to be cultivated into a Huma is 1,750 hectares. The difference if the need for one year's wasteland is 53 hectares. Simultaneously the arable land area of $\pm 2,136.58$ hectares in the Ulayat area continues to be used as a new settlement and cu rrently (2019) has reached 67 villages. Baduy Dalam residents are prohibited from a farm outside of Baduy Dalam ulayat land. The area of arable land and for Baduy Dalam residents based on their claim is not more than 700 hectares for three villages because 3000 -hectare land has been pegged as "Leuweung Kolot" that can not be used for farming.

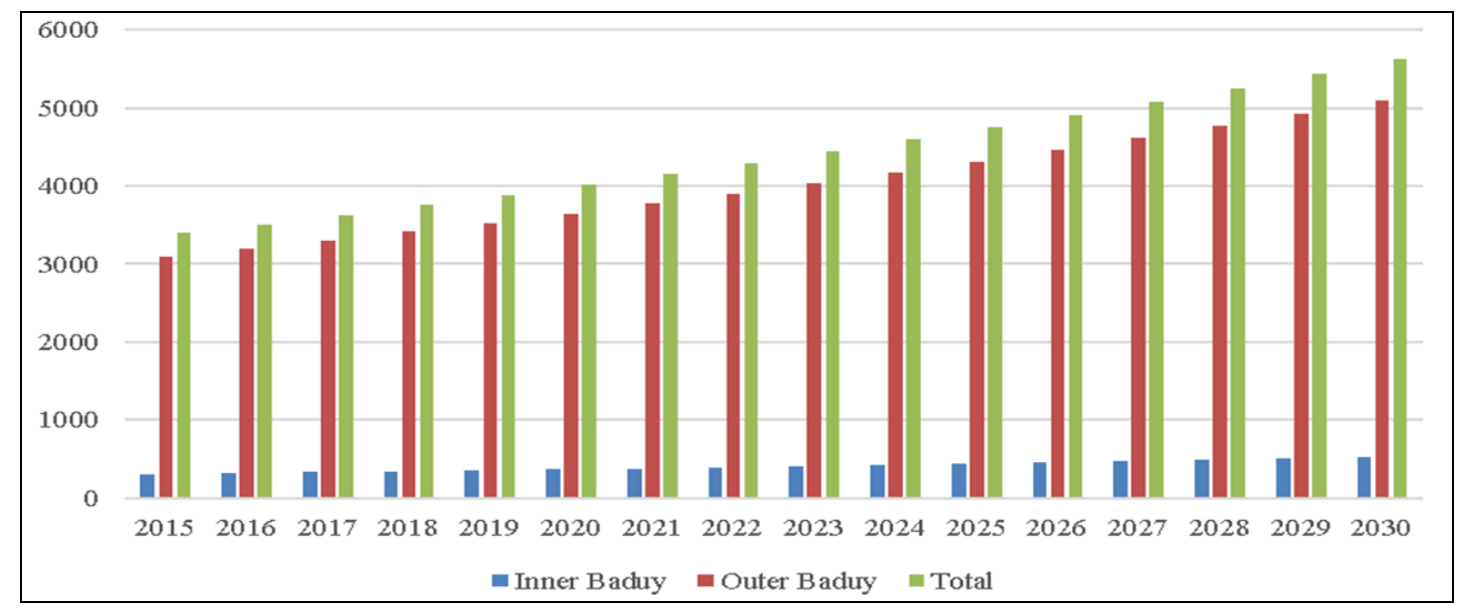

Figure 3. Estimated Growth of Baduy Household in 2015-2030 ( BPS, 2019)

The limited land makes the Baduy residents no longer use the fallow system (resting the land that has been tilled); this started in 2016. The effect is that the land is farmed continuously so that the level of soil fertility decreases, and the possibility of crop failure is increased. The following table shows the fallow system predictions that will end in 2022 if there is no additional land. Even if there is an additional land, it is not significant, but it still makes the system out of control.

Table 1. The Need for Land for Farming of Baduy ResidentsIf One head of household Needs $1 / 2$ Hectares

(Land area of Ulayat for settlement \& arable farming 2.136.58 hectares) (Dasta source: BPS, 2019)

\begin{tabular}{|c|c|c|c|c|c|}
\hline No & Year & Number Of Head Of Households & Land Requirements/Year & Increased Land Requirements/Year & Land Resting Period (FALLOW) \\
\hline 1 & 2015 & 3.395 & $1.697,5$ Hectares & - & - \\
\hline 2 & 2016 & 3.511 & $1.755,5$ hectares & 58 hectares & Fallow starts unstable \\
\hline 3 & 2017 & 3.631 & $1.815,5$ hectares & 60 hectares & Fallow starts unstable \\
\hline 4 & 2018 & 3.755 & $1.877,5$ hectares & 62 hectares & Fallow becomes more unstable \\
\hline 5 & 2019 & 3.883 & $1.941,5$ hectares & 64 hectares & Fallow becomes more unstable \\
\hline 6 & 2020 & 4.016 & 2.008 hectares & 66,5 Hectares & Fallow Uncontrolled \\
\hline 7 & 2021 & 4.153 & $2.076,5$ hectares & 68,5 hectares & Fallow uncontrolled \\
\hline 8 & 2022 & 4.295 & $2.147,5$ hectares & 71 hectares & Cannot be able to fallow \\
\hline 9 & 2023 & 4.442 & 2.221 hectares & 74 hectares & Crisis zone land \\
\hline 10 & 2024 & 4.594 & 2.297 hectares & 76 hectares & Crisis zone land \\
\hline 11 & 2025 & 4.751 & $2.375,5$ hectares & 78,5 hectares & Crisis zone land \\
\hline 12 & 2026 & 4.914 & 2.457 hectares & 81,5 hectares & Crisis zone land \\
\hline 13 & 2027 & 5.082 & 2.541 hectares & 84 hectares & Crisis zone land \\
\hline 14 & 2028 & 5.256 & 2.628 hectares & Crisis zone land \\
\hline 15 & 2029 & 5.435 & $2.717,5$ hectares & 93 hectares & Crisis zone land \\
\hline 16 & 2030 & 5.621 & $2.810,5$ hectares & & \\
\hline
\end{tabular}

Based on Table 1 it seems that in the next three years from 2019, wasteland stock for Ngahuma needed for Baduy residents in play at land is not available. Based on the data in 2022, the estimated land need/ year for ngahuma increases to 2,147.5 hectares whi le available land is only $\pm 2,136.58$ hectares and even for settlements and arable land. Therefore, the total population reaches 13,755 inhabitants; the number of heads of households is 4,295.The land's impact can not be given time to rest (Fallow), so that land fertility decre ases, and the fatal result is crop failure. They will be faced with a fundamental \& principle multi-crisis with such a situation.

In the following year, the population and head of households are not decreasing but also increasing. This situation demands additional land cubication of about 74 hectares. In 2023 the need to be 2,221 hectares and have entered the Crisis Zone minus tens of hectares, and 
every year the minus continues to increase (Table 2). Crop failure means that rice income is reduced even to zero, and this situation indicates the food shortage disaster (rice) already, while and will continue to occur with increasing intensity.

Table 2. Land Needs For Farming Specifically For Baduy Dalam Residents If One Head of Household Needs Half a Hectare (Ulayat Land area for settlement $\&$ arable land \pm 700 hectares) (Dasta source: BPS, 2019)

\begin{tabular}{|c|c|c|c|c|c|}
\hline No & Year & Number Of Head Of Households & Land requirements/year & Increased land requirements/year & Land Resting Period (Fallow) \\
\hline 1 & 2015 & 308 & 154 hectares & - & 4 years \\
\hline 2 & 2016 & 319 & 159,5 hectares & 58 hectares & 4 years \\
\hline 3 & 2017 & 330 & 165 hectares & 60 hectares & 4 years \\
\hline 4 & 2018 & 342 & 171 hectares & 62 hectares & 3 years \\
\hline 5 & 2019 & 354 & 177 hectares & 64 hectares & 3 years \\
\hline 6 & 2020 & 367 & 183,5 hectares & 66,5 hectares & 3 years \\
\hline 7 & 2021 & 380 & 190 hectares & 68,5 hectares & 3 years \\
\hline 8 & 2022 & 394 & 197 hectares & 71 hectares & 2 years \\
\hline 9 & 2023 & 408 & 204 hectares & 74 hectares & 2 years \\
\hline 10 & 2024 & 423 & 211,5 hectares & 76 hectares & 2 years \\
\hline 11 & 2025 & 438 & 219 hectares & 78,5 hectares & 1 year \\
\hline 12 & 2026 & 454 & 227 hectares & 81,5 hectares & 1 year \\
\hline 13 & 2027 & 470 & 235 hectares & 84 hectares & fallow starts unstable \\
\hline 14 & 2028 & 487 & 243,5 hectares & 87 hectares & fallow starts unstable \\
\hline 15 & 2029 & 504 & 252 hectares & 89,5 hectares & fallow becomes more unstable \\
\hline 16 & 2030 & 522 & 261 hectares & 93 hectares & fallow becomes more unstable \\
\hline
\end{tabular}

\section{CONCLUSIONS}

\section{Alternative Solutions for the Baduy}

Based on field studies and observations of estimated land needs, it is proven that the demand for land continues to increase in line with population growth and the head of the household. Hence, based on statistics, there is only one solution required to increase the number of land cubication for the baduy community, while other alternatives are currently complicated to implement. However, when it is assessed with the theory of social engineering and social intervention, several solutions are still possible to slow the coming of a disaster of food shortages and cultural extinction (fade up). This proposition is appropriate with Iskandar's et al. (2018c) research findings that the Baduy community must immediately assess the ecological needs to fulfill the land needs in the middle of the existence of ngahuma.

The first solution applied for Baduy Luar residents is by allowing ngahuma outside of ulayat land with a system of leasing or buying privately owned land, which has been running for a long time. Do not be surprised if the Baduy Luar residents are found spre ad of in the fields and even settled family life in areas outside the Baduy with nyaung-nyaung makes saung huma at their place of farming. This solution is faced with obstacles and challenges that are in the outer areas of Baduy's companions. The land is getting narrower because it is used by settlements and projects to use and extract natural resources, and not all Baduy Luar residents can buy land.

The second solution offered by custom is by reducing the area of farms like ngahuma land, each family from half a hectare to a quarter hectare. This solution is more commonly done by the residents of Baduy Dalam with the principle of justice to avoid resistance and commotion or strife among residents because the primary reason of Baduy Dalam residents is prohibited to ngahuma outside the Baduy ulayat land. In an interview, Jaro Sami stated, "Our thoughts and concerns are the crisis of land that still do not gain even increasing narrows and lost its fertility due to the number of population that working on the land for ngahuma is increasing". In the past, one / a family can work on one hectare. One hectare has been divided up by eight tenants because the crop size decreases, or the yields are also gett ing smaller, and even many have experienced famine due to crop failure. In the future, many citizens will crazy cause do not have anything (Ungrateful because low). The third solution is an external solution through social engineering and social intervention by outsiders Baduy, that is, groups of Baduy observers, both sympathizers and academics, and researchers concerned with Baduy, including the most competent and primary, are the government / the State. They overshadow their future fate and protect people and society.

The Fourth solution stated by the Baduy Dalam Customary Figure mentions: more population means land decreases since even only a little field must be obliged ngahuma; if possible, it must be helped/assisted by the government as a way out. One of the solutions that can be taken by the government is to expand the customary land owned by the Baduy community through the customary ulayat land expansion program; the second is another assistance in the form of a crisis response program using money, rice, or dishes. If more solutions are not taken, the baduy community will face confusion regarding ngahuma, which has been carried out from generation to generation as a tradition. However, the stomach needs to be filled with food, that is a fact. When someone offers a solution to apply for an old-fashioned forest is opened for ngahuma (farming). Based on the elderly speech, it cannot be changed at all or opened because later, if the forest is destroyed, there will be disasters everywhere because it is a natural lung for the whole world; it is not a covered forest. How ever, a forest entrusted by the Almighty if the forest is closed can be opened, if the forest entrusted from beginning to end can not be opened for anything if the term forestry Is the same as forest cover can be opened. However, the forest in wiwitan is entrusted forest from ancestors that cannot be disturbed by anyone; it can curse its impact on the country, others, and even everywhere. (interrupted questions from the author: for five years, there have been reports about crop failures according to Mr. Jaro?). Crop failure is due to the shortage of land due to the second natural season/weather conditions. The point is still reduced income caused by reduced land area, originally one hectare then to be three-quarters of a hectare then half a hectare to a quarter hectare, the ground is getting narrower. Baduy Dalam people ngahuma must be in the Baduy Ulayat land. Can it move outside? It should not be able at all, and it cannot be the slightest policy because stepping over the Badu yLuar is therefore not allowed. Even though the term is only the seed of sabatok is still carried out in the Baduy Dalam region. Indeed if the government doe s not assist these people, many will be crazy because they are poor. There will undoubtedly be many who fade in carrying out cu stomary law, many who do not obey customary law, and cooperation culture will break/fall apart due to being too far away. If it is far away, then cooperation will not be active anymore. If this situation is left, then the name of custom destruction can start from food destruction thoughtfulness and fears of the coming disaster of food shortages. The destruction of cultural customs for a while in the past five years can still be resolved. However, for the next five years and so on ... it feels we are increasingly pressed ... ".

Referring to some solutions offered, the writer tends to choose the final solution: the government should extend assistance in the form of land grants that will be used as ngahuma for the Baduy community. Positively, this affects the Baduy legal system, which undergoes modification. If their legal system prohibits ngahuma outside ulayat land, then it is time for this legal system to be modifi ed. The prohibition 
for Baduy Dalam to ngahuma outside of kajeroan land needs to be modified by allowing them to ngahuma outside their territory. This consequence is a challenging situation for Baduy, who has lived for centuries with their legal system. However, on the other hand, the obligation of ngahuma and the need for rice income also became a problem that they faced.

\section{REFERENCES}

Ardan, R. (2008). The upper integument lip of Baduy and the nearby living Sundanese in South Banten, West Java, Indonesia. Dental Journal (Majalah Kedokteran Gigi), 41(3), 118-122. http://dx.doi.org/10.20473/j.djmkg.v41.i3.p118-122

Barendregt B., \& Wessing R. (2008). Centred on the source: Hamlets and houses of Kanekes (Baduy). In: Schefold R., et al Indonesian houses; Survey of vernacular architecture in western Indonesia, Leiden: KITLV Press, 551-596. https://doi.org/10.1163/9789004253988_019

Becker, H., Berger, P., Luckmann, T., Burawoy, M., Gans, H., Gerson, K., \& Horowitz, R. (2002). Observation and interviewing: Options and choices in qualitative research. Qualitative research in action, 6, 200-224. https://dx.doi.org/10.4135/9781849209656.n9

Bukhori-Muslim, A. (2015). Imagined Baduy children. In: Brown J., Johnson N.F. (eds) Children's Images of Identity. Transgressions: Cultural Studies and Education, 107. Springer, Rotterdam. https://doi.org/10.1007/978-94-6300-124-3_9

Chalil, D., Sidique, S.F., Barus, R., Abdul Hadi, A.H.I., Khaliqi, M., \& Fatoni, M.I. (2018). Local wisdom of indigenous society in managing their customary land: a comparative study on tribes in Indonesia. In E3S Web of Conferences, EDP Sciences, Eds., 52, 00023. https://doi.org/10.1051/e3sconf/20185200023

Hakiki, K.M. (2015). Keislaman Suku Baduy Banten: Antara Islam dan Islam Sunda WiwitanIslamic Baduy tribe in Banten. [Between Islam and Sundanese Islam Wiwitan]. Refleksi, 14(1), 25-54. https://doi.org/10.15408/ref.v14i1.9576

Mohammad, Z.D. (2017). Kabuyutan sacred sites in the sundanese landscape of indonesia: a reevaluation from the perspective of sustainable landscape management. Doctoral Dissertation. Kyoto University, 1-21. https://info:doi/10.14989/doctor.k20745

Hidayati, N.A., Waluyo, H.J., Winarni, R., \& Suyitno. (2020). Exploring the Implementation of Local Wisdom-Based Character Education among Indonesian Higher Education Students. International Journal of Instruction, 13(2), 179-198. https://doi.org/10.29333/iji.2020.13213a

Holil, M. (2020). Myths of Nyi Pohaci Sanghyang Sri on Sundanese Ethnic: Efforts to Reconstruct the Values of Environmental Conservation. In IOP Conference Series: Earth and Environmental Science, 469(1), 012054, IOP Publishing Ltd. http://dx.doi.org/10.1088/1755-1315/469/1/012054

Huberman, M., \& Miles, M.B. (2002). The qualitative researcher's companion. Sage. https://dx.doi.org/10.4135/9781412986274

Ichwandi, I., \& Shinohara, T. (2007). Indigenous practices for the use of and managing tropical natural resources: A case study on the Baduy community in Banten, Indonesia. Tropics, 16(2), 87-102. https://doi.org/10.3759/tropics.16.87

Iskandar, J. (2007a). Responses to environmental stress in the Baduy swidden system, South Banten, Java. Modern Crises and Traditional Strategies: Local knowledge in island Southeast Asia, Berghahn Books, New York-Oxford, 112-132.

Iskandar, J., \& Iskandar, B.S. (2017b). Local knowledge of the Baduy Community of South Banten (Indonesia) on the traditional landscapes. Biodiversitas Journal of Biological Diversity, 18(3), 928-938. https://doi.org/10.13057/biodiv/d180309

Iskandar, J., Iskandar, B.S., \& Partasasmita, R. (2018c). Site Selection and Soil fertility management by the Outer Baduy People (Banten, Indonesia) in maintaining swidden cultivation productivity. Biodiversitas Journal of Biological Diversity, 19(4), 1334-1346. https://doi.org/10.13057/biodiv/d190421

Jonsen, K., \& Jehn, K.A. (2009). Using triangulation to validate themes in qualitative studies. Qualitative Research in Organizations and Management, 4(2), 123-150. https://doi.org/10.1108/17465640910978391

Khomsan, A., \& Wigna, W. (2009). Socio-Cultural Food of the Baduy Tribe. Jurnal Gizi dan Pangan, 4(2), 63-71. https://doi.org/10.25182/jgp.2009.4.2.63-71

Kismartini, K., \& Pujiyono, B. (2020). Collaborative Management Model Tanjung Lesung Tourism In Pandeglang District, Banten Province, Indonesia. GeoJournal of Tourism and Geosites, 30(spl2), 868-874. https://doi.org/10.30892/gtg.302spl12-516

Kurnia, A., Sihabudin, A., \& Yustianti, F. (2010). Saatnya Baduy bicara: lojor teu meunang dipotong, pondok teu meunang disambung, gunung teu meunang dilebur, lebak teu meunang dirusak, buyut teu meunang dirobah. Bumi Aksara.

Mulyadi, S., Prabowo, H., \& Chrisnatalia, M. (2019, August). Cultural contact, cultural values, and education for life and work as predictors of future orientation in the Baduy community. In 2nd International Conference on Intervention and Applied Psychology (ICIAP 2018). Atlantis Press. 5(2), 195217. https://doi.org/10.2991/iciap-18.2019.90

Nadroh, S. (2018). Pikukuh Karuhun Baduy The Dynamics of Local Wisdom In The Middle of Modernity. Jurnal PASUPATI,5(2), 196-216. http://dx.doi.org/10.37428/pspt.v5i2.117

Permana, R.C.E., Nasution, I.P., Nugroho, Y.A., \& Putra, H. (2017). Sosialisasi Kearifan Lokal Masyarakat Baduy Dalam Mitigasi Bencana Di Perbatasan Wilayah Baduy. [Dissemination of local wisdom of the Baduy community in disaster mitigation at the border of the Baduy area]. Paradigma, Jurnal Kajian Budaya, (In Indonesian), 4(1), 27-41. http://dx.doi.org/10.17510/paradigma.v4i1.157

Putri, G.S., Meiliyana, M., Oktapiandi, R.N.G., \& Fasya, M. (2019). Conservation of Organic Agricultural Systems in Ethno-Agricultural Lexicons [Ethnolinguistic Study in Baduy Traditional Village]. SSRN Conference Paper, SSRN 3431167. http://dx.doi.org/10.2139/ssrn.3431167

Sodikin, S. (2017). Traditional Wisdom of Adat Law Baduy Community In Farming System In Kanekes Village, Leuwihdamar Lebak Banten. Jurnal Cita Hukum, 5(1), 89-108. http://10.15408/jch.v5i1.5398

Solikhah, N. (2020). Ethnic tourism and sustainable of vernacular settlement in Cibeo Village, Baduy Dalam. In IOP Conference Series: Earth and Environmental Science, IOP Publishing, 452(1), 012021. https://iopscience.iop.org/article/10.1088/1755-1315/452/1/012021

Sumaryadi, I.N., Hasan, E., \& Lukman, S. (2020). The Role of Socio-Culture and the Factors Affecting the Development of the Baduy Community. International Journal of Science and Society, 2(4), 338-348. https://doi.org/10.200609/ijsoc.v2i4.219

Sutisna, T. (2019). The local farming system based on custom and tradition to achieve sustainable agriculture in Baduy indigenous community. In IOP Conference Series: Earth and Environmental Science, IOP Publishing, 383(1), 012032. https://doi:10.1088/1755-1315/383/1/012032

Taryana, A., Khotimah, F.K.H., Achsani, N.A., \& Arifin, B. (2020). Innovative Food System Risk Management of the Baduy Tribe. Business Review and Case Studies, 1(1), 1-1. https://doi.org/10.17358/brcs.1.1.1

Thomas, D.R. (2006). A general inductive approach for analyzing qualitative evaluation data. American Journal of Evaluation, 27(2), 237-246. https://doi.org/10.1177/1098214005283748

Tou, H. J., Noer, M., Lenggogeni, H., \& Lenggogeni, S. (2020, December). Local Wisdom in Spatial Planning for Rural Tourism Development. In Proceedings of Tourism Development Centre International Conference, 154-161, Sciendo. https://doi.org/10.2478/9788395720406-018

Utomo, S.H., Wulandari, D., Narmaditya, B.S., Ishak, S., Prayitno, P.H., Sahid, S., \& Qodri, L.A. (2020). Rural-Based Tourism And Local Economic Development: Evidence From Indonesia. GeoJournal of Tourism and Geosites, 31(3), 1161-1165. https://doi.org/10.30892/gtg.31330-553

***BPS. (2019). Badan Pusat Statistik Kabupaten [Lebak Agency on Statistics].(In Indonesian). Retrieved from https://lebakkab.bps.go.id/subject/12/kependudukan. 